\title{
Prevalence of Modern Teaching Method among Senior High School Students Matronillo M. Martin ${ }^{1 *}$, Gilbert Laciste ${ }^{2}$, and Kristine Concepcion ${ }^{1}$
}

\author{
${ }^{1}$ College of Advanced Education, Ifugao State University-Potia Campus, Philippines \\ ${ }^{2}$ University of La Salette, Santiago City, Philippines \\ *Corresponding author: matt_martin12280@yahoo.com \\ DOI: https://doi.org/10.37134/ejsmt.vol6.1.1.2019
}

Received: 09 May 2019; Accepted: 04 June 2019; Published: 21 June 2019

\begin{abstract}
The main purpose of this study is to determine the prevailing modern teaching methods in teaching-learning process. The descriptive-quantitative method was employed using a questionnaire as data gathering instrument. Frequencies, percentages and weighted mean were used to treat the data. The target population of the study was 286 of the senior high school students of the University of La Salette, Inc. - Santiago City during the school year 2018-2019. The study showed that modern teaching method has a positive impact on the learning of the students. It gives a lot of benefits that characterize a life-long learning. Also, through the modern teaching a method, students would be able to learn some values that would lead them to success. It also revealed that among the four-teaching method, brainstorming is the most effective for the students to learn. Based on the findings and conclusions of the study, it was recommended that teachers need to continually develop a method that would let their students easily to learn and in order to cope up with the needs of the students. They should always reflect on their own methods to improve the teaching learning process. Also, in choosing an appropriate teaching method, teachers should consider his or her subject matter and students. It is not necessary that brainstorming is always effective in teaching learning process thus, when a teacher employ a teaching method, he/she needs to exert an effort to fully experience the effectiveness of the teaching method. It also recommended that future researchers must use an experimentation design to determine the effectiveness of the different teaching method.
\end{abstract}

Keywords: education, modern teaching method, brainstorming, teaching-learning process

\section{INTRODUCTION}

Education is a light that shows the mankind the right direction to surge [1] The purpose of education is not just making a student literate but adds rationale thinking, knowledgeability and self-sufficiency. When there is a willingness to change, there is hope for progress in any field. Creativity can be developed and innovation benefits both students and teachers. If education fails to inculcate self-discipline and commitment to achieve in the minds of student, it is not their fault. Converting education into a sport and learning process has to generate interest in the students and motivate them to stay back in the institution than to run away from it. Education should become a fun and thrill to them rather than burden and boredom. It is an integral part of their growth and helps them become good citizens. "Education is an engine for the growth and progress of any society. It not only imparts knowledge, skills and inculcates values, but is also responsible for building human capital which breeds, drives and sets technological innovation and economic growth. In today's era, accelerating technological change demands a change in education systems to more of modern education format [2]. Since new technologies are appearing at such a fast pace. Primary education will only form a foundation for future learning. It is no longer enough to be second best: everyone needs $21^{\text {st }}$ century skill not just better skills but different skills [3]. To respond these socio-economic skills for life and instilling a love learning. Since modern day education is aided with a variety of technology; computers, projectors, internet and many more wherein everything that can be simplified has been made simpler, we need to think a way to organize learning so that those who are excluded by geography, poverty or learning style have real 
chance to experience these changes in education. With all these changes happens in education, teaching is also changing in respect of the classroom experiences.

The primary purpose of teaching is to bring fundamental change in the learner [4]. To facilitate the process of knowledge transmission, teachers should apply appropriate teaching methods that best suits the specific objectives and level exit outcomes. Substantial research on the effectiveness of teaching methods indicates the quality of teaching is reflected by the achievements of the learners. Teaching is a process that involves bringing about desirable changes in learners so as to achieve specific outcomes. In order for the method used for teaching to be effective [5], maintains that teachers need to be conversant with numerous teaching strategies that take the recognition of the magnitude of complexity of the concepts to be covered. He indicated that in order to bring desirable changes in students, teaching methods used by educators should be best for the subject matter [6]. Furthermore, to sustain the teaching methods works effectively in order suit learners' needs every learner must interpret and respond to questions in a unique way. As such, alignment of teaching method with students needs and preferred learning influence students' academic attainments [7]. Then, in order to cope up with the trends in this generation, researchers suggest different modern teaching method which are listed below:

It is an instructional methodology in which students learn important skills by doing actual projects. The acquisition and structuring of knowledge in PBL are thought to work through the following cognitive effects, initial analysis of the problem and activation of prior knowledge through small-group discussion, elaboration on prior knowledge and active processing of new information, restructuring of knowledge, construction of a semantic network, social knowledge construction and learning in context [8].

It is often referred to as a form of problem-based learning, which describes an environment in which learning is driven by a process of inquiry owned by the student. The problem can be presented in various forms - question, task, experiment. Some theories suggest that learning occurs as students collaboratively engage with concepts in meaningful problem solving. In this view, knowledge is seen as a tool for thinking and for enabling learners to participate in meaningful activity. It is also based on learning by discovering, on constructivism and on active interaction of teachers and pupils. An outcome based on the heuristic method, in the Czech Republic very popular, are the activities of young debrouillards. The common axes of their philosophy are: use of scientific process, leader guided creativity, use of cheap and non-sophisticated materials. The method includes entertaining activities to stimulate the kids' exposure to the scientific phenomena they meet in the everyday environment, to develop the child's curiosity and analytic mind, to have training effects on the family, scholar and social scales.

It is a group creativity technique designed to generate a large number of ideas for the solution of a problem. In this strategy, the groups could double their creative output with brainstorming. The most important outcome of brainstorming is improving team work. The teacher has to create a criticism-free environment, to present the problem and organize the discussion. It must be clear, how to measure progress and success, the way for evaluation of the process. The solution of brainstorming must be clear for all [8].

It is a process that closely relates to the utilization of learning technologies due to the fact that students are familiar with the technology and they will learn better of technology-based environment, the issue of ICT integration elements and components [10]. It is right to say that almost all ranges of subjects start from mathematics, science, languages, arts and humanistic and other fields can be learned more effectively through technology-based tools and equipment. Now, there are lots of modern gadgets which can be used for improving for the teaching inside the classroom. Here is the list of the popular equipment which can be used in teaching [3]. First, the use of Computers and Laptops with WIFI connection in the classroom. It is the most important tool of modern teaching methods. Teachers demonstrates the subject in the laptop or computers which is connected to the laptop and computer of the students through Wi-Fi connection. Second, use of LCD projector in the classroom. Use of LCD screens in the educational institutions is becoming very common nowadays. Teacher prepares the power point slides and which are 
displayed on the LCD screen with the help of a projector. The projector can also be connected to a laptop/computer for displaying the relevant videos of the subject on the projector. Lastly, the use of interactive whiteboards in the classroom. Whiteboards are very interactive and provides the touch control of the computer applications. On the whiteboard, a teacher or student can draw, write or manipulate images that provides a very interactive and interesting platform.

The main problem of this study was to determine the effectiveness of modern teaching method in a teaching learning process. Specifically, the study sought to answer the following questions: (1) What is the level of perception of the students to the different modern teaching methods? and What is the prevailing modern teaching method to the students?

\section{METHODOLOGY}

The aim of the study was to determine the effectiveness of the modern teaching method. As a result, the descriptive-quantitative method was used. There were 286 senior high school students of the University of La Salette, Incorporated school year 2018-2019. This school is located at Dubinan East, Santiago City. The University of La Salette is a private school that has the largest number of populations in the City. This school is also a Level II PAASCU accredited. The number of samples was determined by using the Lynch

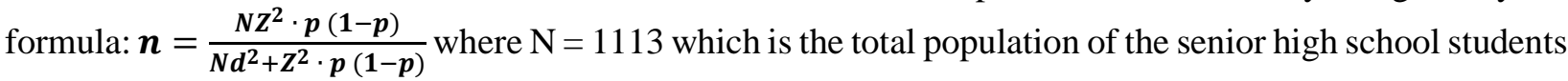
with a 1.96 as value of the normal variables (Z) for reliability level (d) of $95 \%$ and 0.5 as the largest possible proportion (p). Random sampling will be used to determine the respondents.

The research instrument used was a questionnaire adapted from Sultana (2016) specifically designed for the students. The researchers sought the permission from the school authorities with a letter of introduction from the school principal. During the actual day, the questionnaire was distributed to all sample with the permission from the school's authorities and teachers concerned. Coordination was done to establish an appropriate time to administer the questionnaire to the students. Thereafter, the group was supervised and collected all the completed questionnaire, then properly kept by the researchers.

In order to arrive at a certain interpretation of data, the five-point Likert scale was used. The collected data was checked, read and marked. Grouping and coding were done according to the themes or variables considered for research which would reflect the objectives. The data were captured in a Statistical Package for Social Sciences (SPSS) from which the analysis was done. The quantitative method was used in the study to determine the prevailing modern teaching method, the weighted mean was computed.

\section{RESULTS AND DISCUSSION}

\section{Students' perception towards modern teaching method}

Table 1 shows the students perception towards project-based learning in general. The overall mean of the perception of the students in project-based learning is 4.28 which is interpreted as strongly agree. Thus, project-based learning has a positive impact to the students. Looking closely to the table, majority of the students stated that project-based learning helps the students develop their collaboration skills with a weighted mean of 4.32 which is interpreted as strongly agree. Followed by the perception of the students that project-based learning helps students to relate concepts with the lesson and project-based learning makes students more active with a weighted mean of 4.31 and 4.29 which is also interpreted as strongly 
agree. The perception of the students that project-based learning helps students to get the gist of the lesson for the class and grab their attention easily has an equal weighted mean which is 4.23 . Even that these perceptions have the lowest weighted mean it is still interpreted as strongly agree. This finding is consistent to the research conducted by Musa, et.al (2010) that project-based learning requires students to work in groups and promote team building, and this is because working a project in group is better than working alone. Additionally, Belle (2010) stated that when a student worked collaboratively, there is an expectation that each student will contribute necessary ideas that will help the project more interesting.

Table 1 Mean and quantitative description of project-based learning

\begin{tabular}{llll}
\hline \multicolumn{1}{c}{ Project-Based Learning } & Mean & Qualitative Description \\
\hline 1. It helps the students grab their attention easily. & 4.23 & Strongly Agree \\
2. It makes students more active. & 4.29 & Strongly Agree \\
3. It helps the students develop their collaboration skills. & 4.32 & Strongly Agree \\
4. It helps students to relate concepts with the lesson. & 4.31 & Strongly Agree \\
5. It helps students to get the gist of the lesson for the \\
class
\end{tabular}

Table 2 presents the students' perception towards using inquiry-based learning in general. The overall mean of this method is 4.25 which is interpreted as strongly agree. Looking closely at the table per item, it was observed that item 2 (It helps the students develop their critical and analytical thinking skills) has the highest weighted mean among the 5 perceptions of the students with regards to inquiry-based learning and it is interpreted as strongly agree.

Table2 Mean and quantitative description of inquiry-based learning

\begin{tabular}{llcc}
\hline \multicolumn{1}{c}{ Inquiry-Based Learning } & Mean & Qualitative Description \\
\hline $\begin{array}{l}\text { 1. It helps the students to make logical connection with } \\
\text { the class. }\end{array}$ & 4.27 & Strongly Agree \\
$\begin{array}{l}\text { 2. It helps the students develop their critical and analytical } \\
\text { thinking skills. }\end{array}$ & 4.35 & Strongly Agree \\
3. It is easily to maintain. & 4.14 & Agree \\
$\begin{array}{l}\text { 4. It helps the students' portrait the clear idea to identify } \\
\text { the objectives for the class. }\end{array}$ & 4.23 & Strongly Agree \\
5. It helps the students trigger the background knowledge \\
for the students.
\end{tabular}

Item 1 (It helps the students to make logical connection with the class), item 5 (It helps the students trigger the background knowledge for the students) and item 4 (It helps the students' portrait the clear idea to identify the objectives for the class) was also interpreted as strongly agree with a weighted mean of 4.27, 4.24 and 4.23 for ranks 2, 3 and 4, respectively. Item 3 (It is easily to maintain) has the lowest weighted 
mean which is 4.14 and interpreted as agree. The result shows that inquiry-based learning is helps the students learning improved. This finding was supported by Towns and Sweetland (2008) that inquiry-based learning develops and validate habits of mind. They claim that students allow to draw conclusions that will develop their capability to think. Additionally, Barron and Hammond (2008) mentioned that inquiry-based learning involves students to explore meaningful problems. Identifying what they need to know in order to come up with a strategy that will serve as the best way to develop students' critical and analytical thinking. The result is also the same to the research conducted Damodharan (2012) that inquiry-based learning produces a graduate who are creative and can think critically and solve challenge problems.

Table 3 shows the students' perception towards brainstorming. Overall extent of this teaching method is strongly agreeing with a weighted mean of 4.36. Among each perception, item 2 (It encourages students to communicate more with their classmates) ranked first with a weighted mean of 4.39 while item 5 (It increases students' confidence to participate in a class discussion) got the lowest weighted mean which is 4.32 but still all the perceptions of the students toward brainstorming as one of the modern teach method was interpreted as strongly agree. This implies that brainstorming has a positive impact on the students learning and considered as an effective teaching method.

Table 3 Mean and quantitative description of brainstorming

\begin{tabular}{|c|c|c|}
\hline Brainstorming & Mean & Qualitative Description \\
\hline 1. It helps the students improve their teamwork. & 4.36 & Strongly Agree \\
\hline $\begin{array}{l}\text { 2. It encourages students to communicate more with their } \\
\text { classmates. }\end{array}$ & 4.39 & Strongly Agree \\
\hline 3. It is fun, interesting and engaging. & 4.36 & Strongly Agree \\
\hline $\begin{array}{l}\text { 4. It enables students to express their ideas and thoughts } \\
\text { better. }\end{array}$ & 4.38 & Strongly Agree \\
\hline $\begin{array}{l}\text { 5. It increases students' confidence to participate in a } \\
\text { class discussion. }\end{array}$ & 4.32 & Strongly Agree \\
\hline Overall & 4.36 & Strongly Agree \\
\hline
\end{tabular}

The finding was supported by Sabarun (2015) that brainstorming associate ideas and stimulate thinking and share it with others and through with these benefits, students can easily learn especially students nowadays are considered as millennials wherein they can learn more if they are active. In addition, brainstorming brings new ideas to tackle particular problem that will encourage them to share their ideas to others.

Table 4 presents the students' perception with regards to the computer-based learning. The overall mean of this teaching method is 4.17 which is interpreted as agree. Looking closely to the table per item, it was observed that item 2 (Multimedia allows students to be more creative and imaginative) has the highest weighted mean among the different students' perception about computer-based learning and it is interpreted as strongly agree. Item 1 (The used of multimedia as a teaching aid in discussion is a major part of class discussion) was ranked second with a weighted mean of 4.24 which is also interpreted as strongly agree. Item 3 (The use of ICT promotes active and engaging lesson), item 4 (Students learn more effectively with the use of ICT) and item 5 (The students are more behaved and under control with the use of ICT) interpreted as agree with a weighted mean of 4.18, 4.15 and 4.01 for rank 3, 4 and 5 respectively. learning situation. 
Table 4 Mean and quantitative description of computer-based learning

\begin{tabular}{|c|c|c|}
\hline Computer-Based Learning & Mean & Qualitative Description \\
\hline $\begin{array}{l}\text { 1. The used of multimedia as a teaching aid in } \\
\text { discussion is a major part of class discussion. }\end{array}$ & 4.24 & Strongly Agree \\
\hline $\begin{array}{l}\text { 2. Multimedia allows students to be more creative and } \\
\text { imaginative. }\end{array}$ & 4.26 & Strongly Agree \\
\hline 3. The use of ICT promotes active and engaging lesson. & 4.18 & Agree \\
\hline 4. Students learn more effectively with the use of ICT. & 4.15 & Agree \\
\hline $\begin{array}{l}\text { 5. The students are more behaved and under control } \\
\text { with the use of ICT. }\end{array}$ & 4.01 & Agree \\
\hline Overall & 4.17 & Agree \\
\hline
\end{tabular}

According to Sultana (2016), multimedia is considered as fun, colorful, engaging, and motivating and attention grabbing for the class. Students are considered as millennials and they preferred a technology based to support their interest that ICT in education would enhance students learning. He also agreed that ICT helps to improved classroom

\section{Most effective modern teaching method}

Table 5 presents the different modern teaching method. Majority of the students states that the best modern teaching method is brainstorming with a frequency of 103 which is $36.01 \%$ of the total respondents. This happens because this method requires students to critically and analytically think to solve a problem It also promotes collaboration and ability to express ideas to others (Friedlander, 2013). This finding is in contrast to the research conducted by Holubova (2010) that brainstorming was found out as very difficult for the students. The main problem was telling the ideas allowed. But with this problem, this teaching method will help the students boost their self-esteem and self-confidence.

Table 5 Mean and quantitative description of modern teaching methods

\begin{tabular}{llcc}
\hline \multicolumn{2}{r}{ Modern Teaching Methods } & Frequency & Percentage \\
\hline 1. & Project-Based Learning & 62 & 21.68 \\
2. & Inquiry-Based Learning & 53 & 18.53 \\
3. $\quad$ Brainstorming & 103 & 36.01 \\
4. & Computer-Based Learning & 68 & 23.78 \\
\hline & Total & 286 & 100.00 \\
\hline
\end{tabular}




\section{CONCLUSION}

In view of afore cited findings, it is concluded that modern teaching method has a positive impact on the learning of the students. It gives a lot of benefits that characterize a life-long learning. Also, through the modern teaching method, students will be able to learn values that will lead them to success. Likewise, brainstorming is the most effective for the students to learn. It is a way to associate ideas among their colleagues the will develops their ability to collaborate and stimulate thinking in order to develop their critical and analytical thinking.

\section{REFERENCES}

[1] Khurshid, F. and Ansari, U. (2012). Effects of Innovative Teaching Strategies on Students' Performance. Double Blind Peer Reviewed International Research Journal, Global Journals of Human Social Science Volume 12 issue 10 version 1.0. National University of Modern Languages, Islamabad. Online ISSN: 2249-460x \& Print ISSN: 0975-587X

[2] Damodharan V. S and Rengarajan V. (2012). Innovative Methods of Teaching.Rex Book Publishing Company.

[3] Gupta, S. (2010). Traditional Vs. Modern Teaching Methodology., Institute of Professional studies, Indore

[4] Tebabal, A. \& Kahssay, G. (2011), “The effects of student-centered approach in improving students' graphical interpretation skills and conceptual understanding of kinematical motion," Lat. Am. J. Phy. Edu, 5(2): 374-381.

[5] Ayeni, A.J. (2011), "Teachers professional development and quality assurance in Nigerian Secondary Schools," World Journal of Education, 1(2):143-149

[6] Adunola, O. (2011), “The Impact of Teachers' Teaching Methods on the Academic Performance of Primary School Pupils in Ijebu-Ode Local cut Area of Ogun State," Ego Booster Books, Ogun State, Nigeria.

[7] Zeeb, Ralph E. (2013). Teaching Methods and Students' Academic Performance., International Journal Of Humanities and Social Science Invention Volume 2 Issue 9. PC Training \& Business College; South Africa. ISSN (Online): 2319 - 7722, ISSN (Print): 2319 - 7714 www.ijhssi.org

[8] Schmidth, G. V. (2008). Traditional vs. Modern Teaching Methods: Advantages and Disadvantages of Each., Masaryk University

[9] Jamieson-Proctor, R., Albion, P., Finger, G., Cavanagh, R., Fitzgerald, R., Bond, T., \& Grimbeek, P. (2013). Development of the TTF TPACK Survey Instrument. Australian Educational Computing, 27(3),26-35.

[10] Musa, Faridah D., Mufti, Norlaila M., Latiff, Rozmel A. and Amin Maryam M. (2011). Project-based Learning: Promoting Meaningful Language Learning for Workplace Skills. Elsevier Ltd., Universiti Kebangsaan Malaysia. doi: 10.1016/j.sbspro.2011.05.027

[11] Ghavifekr, S., Wan, A. and Rhosdy W. (2015). Teaching and Learning with Technology: Effectiveness of ICT Integration in Schools. University of Malaya, Malaysia

[12] Town, Ronald and Sweetland, Julie (2008). The effectiveness of using brainstorming technique in writing paragraph across the different level of achievement at the second semester English department students of Palangka Raya State Islamic Institute, Indonesia.

[13] Sabarun, Sharon (2013). Inquiry-Based Learning: A Review of the Research Literature. Alberta Ministry of Education. Galileo Educational Network, University of Calgary

[14] Holubová, R. (2010). Improving the Quality of Teaching by Modern Teaching Methods., Palacky University Olomouc, Czech Republic.

[15] Sultana, Sharmin (2016). Preference towards modern day teaching and traditional teaching aids among the Bangladeshi tertiary level students., Brac University, Dhaka, Bangladesh. 